\title{
ČESKOSLOVENSKÁ POZEMKOVÁ REFORMA NA STATCÍCH CIZINCŮ NA SLOVENSKU. PŘÍPAD BARONSKÉHO RODU VON STEIGER-MÜNSINGEN
}

\author{
VÁCLAV H O R Č I Č K A - JAN Ž U P A N I Č
}

\begin{abstract}
HORČIČKA, Václav - ŽUPANIČ, Jan. Czechoslovak land reform and the estates of foreigners in Slovakia. The case of the baronial von Steiger-Münsingen family. Historický časopis, 2019, 67, 3, pp. 481-500, Bratislava.

The authors were concerned with land reform on the large Hajná Nová Ves estate, which belonged to Maria von Steiger-Münsingen, later Savioli, who had Swiss and later Italian citizenship. The aim was both to identify the main parameters of the land reform on the Hajná Nová Ves estate and compare it with the situation elsewhere, while also finding out how far the implementation of land reform was affected if a landowner could rely on support from the government of a neutral state or later the originally allied Italy. The main aim was to confirm or refute the hypothesis that thanks to foreign protection, von Steiger and her heirs were better treated during the land reform. The authors show that this did not happen, especially because of the owner's lack of negotiating skills.
\end{abstract}

Key words: First land reform. Czechoslovakia. Hajná Nová Ves. Steiger-Münsingen family.

DOI: https://doi.org/10.31577/histcaso.2019.67.3.5

Československá první pozemková reforma stojí spíše ve stínu zájmu českých a slovenských badatelů. Jde o tematiku komplikovanou, pro její obecné zhodnocení dosud chybí dostatek př́ípadových studií. Současně jde o téma významné nejen z pohledu politiky domácí, ale i zahraniční. Řada vlastníků totiž po roce 1918 disponovala cizím občanstvím a do diskusí o způsobu provedení reformy se tak zapojily vlády řady států. Bylo tomu tak i v př́padě Švýcarska, jehož občankami byly majitelky velkostatku Hajná Nová Ves nedaleko Topol'čian Marie von Steiger a její dcera Marie von Walterskirchen. Vzhledem k tomu, že téma pozemkové reformy na výše uvedeném velkostatku dosud nebylo v odborné literatuře uspokojivě zpracováno, bylo třeba vycházet především z nevydaných pramenů. Práce probíhaly v českých, slovenských i zahraničních archivech. Šlo zejména o Archiv ministerstva zahraničních věcí (AMZV) a Národní archiv (NA) v Praze, Slovenský národný archív (SNA) v Bratislavě a o Schweizerisches Bun- 
desarchiv (BAR) v Bernu. Odborná literatura mohla být využita jen k zasazení procesu provádění pozemkové reformy do širších souvislostí.

Cílem této studie je jednak vytyčit hlavní parametry pozemkové reformy na velkostatku Hajná Nová Ves, porovnat je se situaci jinde a současně zjistit, jak významně se do provádění reformy promítla skutečnost, že se někteří velkostatkáŕi, v této př́padové studii rodina von Steiger, mohli oprŕt o ochranu vlády neutrálního státu a posléze původně spojenecké Itálie. Jde o to ověřit, jak intenzivně Švýcarsko a v závěru sledovaného období Itálie do tohoto procesu vstupovaly a potvrdit či vyvrátit hypotézu, že von Steigerové a jejich dědicové díky zahraniční ochraně dosáhli během provádění reformy určitých úlev. Cílem je tedy představit př́padovou studii k provádění pozemkové reformy na majetku neutrálních cizozemců. Shromážděná zjištění budou v budoucnosti sloužit jako podklad pro syntetičtější pojednání o pozemkové reformě na statcích cizích státních př́íslušníků.

Československá pozemková reforma byla zahájena již krátce po vzniku nového státu, v listopadu 1918, kdy bylo príijato první ze série jí upravujících legislativních opatření, tzv. zákon o obstavení velkostatků. ${ }^{1} \mathrm{~V}$ dubnu 1919 byl přijat tzv. záborový zákon, na jeho základě byl zabrán velký pozemkový majetek. ${ }^{2}$ Šlo o majetek, jehož vlastník držel více než 150 hektarů zemědělské nebo 250 hektarů veškeré půdy. Výraz zabrán ovšem neznamenal, že byl majetek rovnou vyvlastněn či dokonce zkonfiskován. V podstatě šlo hlavně o to, že stávající vlastník nesměl se svým majetkem bez souhlasu státu volně nakládat, např́íklad ho prodat, rozdělit apod. ${ }^{3} \mathrm{~V}$ lednu 1920 pak následoval tzv. př́iělový zákon, který stanovil pravidla přidělování zabrané půdy. V dubnu 1920 byl přijat zákon náhradový, který upravoval způsob odškodnění původních vlastníků. Výše náhrady se vypočítávala podle průměrných cen půdy z let 1913-1915, čímž byli velkostatkáři, zvláště ti s rozlohou nad 1000 ha, kterým se náhrada ještě dále snižovala, významně poškozeni. ${ }^{4} \mathrm{~V}$ závěrečném období války totiž ceny půdy dále rostly. Vedle toho byly $\mathrm{v}$ rámci pozemkové reformy přijaty některé další

1 Zákon č. 32 ze dne 9. listopadu 1918 o obstavení velkostatků. Dostupné na internetu: $<$ https://www.epravo.cz/vyhledavani-aspi/?Id=818\&Section=1\&IdPara=1\&ParaC=2>. [cit. 2018-12-01].

2 Zákon č. 215ze dne 16. dubna 1919 o zabrání velkého majetku pozemkového. Dostupné na internetu: $\quad<\mathrm{https}: / /$ www.beck-online.cz/bo/chapterview-document.seam?documentId=onrf6mjzge4v6mrrguxhazrrhbsc2my>. [cit. 2018-12-01].

3 RYCHLÍK, Jan. Pozemková reforma v Československu v letech 1919-1938. In Vědecké práce Zemédělského muzea, 1987-88, roč. 27, s. 127-148.

4 Zákon č. 329 ze dne 8 . dubna 1920 o převzetí a náhradě za zabraný majetek pozemkový (zákon náhradový). Dostupné na internetu: <https://www.epravo.cz/vyhledavani-aspi/?Id=1910\&Section=1\&IdPara=1\&ParaC=2>. [cit. 2018-12-01]. 
zákony. ${ }^{5}$ Nemalý význam mělo zrušení fideikomisů (1924), které komplikovaly provedení pozemkové reformy. ${ }^{6}$

Cílem pozemkové reformy bylo ovlivnit sociální složení venkova a současně podpořit český a slovenský nacionální element v mnohonárodnostním československém státě. Velmi ji propagovala Agrární strana (od roku 1922 Republikánská strana zemědělského a malorolnického lidu), zejména její zájmy drobných a středních vlastníků reprezentující křídlo vedené předsedou strany Antonínem Švehlou. ${ }^{7}$ Vedle výše uvedeného šlo také o to, utišit hlad bezzemků po půdě, přičemž značnou roli zde sehrála i světová válka a nedostatek potravin. Bylo též třeba zajistit válečné navrátilce, invalidy a vdovy. ${ }^{8}$

Tato ze sociálního hlediska nesmírně významná změna poměrů na venkově dopadla nejen na československé občany, ale i na př́islušníky cizích států. Odborná literatura uvádí, že cizincům patřilo v době vzniku Československé republiky asi $21 \%$ veškeré půdy. ${ }^{9}$ Mezi cizinci se jednalo zejména o rakouské, mad’arské a německé státní př́islušníky. Šlo přitom leckdy o obrovské majetky. Např́klad rakouské vyslanectví v Praze odhadovalo rozsah pozemkového majetku několika desítek rakouských vlastníků, většinou bývalých aristokratů, v Československu na téměř 195000 hektarů půdy. ${ }^{10}$ Výše uvedené státy však z pohledu československých úřadů patřily mezi v první světové válce poražené země a to se promítalo i do jejich postupu vůči jejich občanům. Je ovšem otázka, jak Praha postupovala vůči vítězným a neutrálním státům, mezi něž patřilo také Švýcarsko.

Pozemková reforma se dotkla tř́ rodin švýcarských občanů a vedle nich osob s dvojím občanstvím (švýcarským a československým), které ovšem díky tomu

5 HORÁK, Ondřej. Lichtenštejnové mezi konfiskací a vyvlastněním. Příspěvek $k$ poválečným zásahuim do pozemkového vlastnictví v Československu v prvni polovině dvacátého století. Praha 2010, s. 75-85. ISBN 9788072774579.

6 Zákon č. 179 ze dne 3. července 1924 o zrušení svěřenectví. Dostupný na internetu $><$ http:// ftp.aspi.cz/opispdf/1924/089-1924.pdf>. [cit. 2018-12-01].

7 SLEZÁK, Lubomír. Tvůrci, kritikové a odpůrci pozemkové reformy. In Moderni dějiny. Sborník k dějinám 19. a 20. století, 1993, Sv. 1, s. 197-215. ISBN 9788072861590.

8 PUTTKAMER, Joachim von. Die Tschechoslowakische Bodenreform von 1919. Soziale Umgestaltung als Fundament der Republik. In Bohemia. Zeitschrift für Geschichte und Kultur der böhmischen Länder, 2005, roč. 46, Heft 2, S. 315-342. ISSN 0523-8587.

9 KUBAČÁK, Antonín. Provádění pozemkové reformy na majetku cizích státních příslušníků v období první republiky. In Vědecké práce Národního zemédělského muzea, 1991-1992, roč. 29 , s. 33-72.

10 Osterreichisches Staatsarchiv Wien (dále ÖstA), Abteilung Archiv der Republik (dále AdR), Auswärtige Angelegenheiten, Teilbestand Gesandtschaft Prag (dále Ges. Prag), Karton (dále Kt.) 61, Marek an Bundeskanzleramt/Auswärtige Angelegenheiten (dále BKA/AA), Grossgrundbesitzer österreichischer Staatsangehörigkeit in der Tschechoslowakei, 11. 11. 1924, No. chybí. 
měly specielní statut a $\mathrm{v}$ podstatě nebyly předmětem zájmu švýcarské diplomacie. To se týkalo zejména rodu Schwarzenbergů. ${ }^{11}$ Pozornost zde budeme věnovat jedné z výše uvedených rodin. Pozdější baroni Steigerové pocházeli z dnešního kantonu Wallis, kde jsou doloženi již ve 13. století. O století později se usadili v Bernu a získali tamní občanství a následně se rozdělili do dvou linií: Steiger-Münsingen a Steiger-Montricher.

Zmíněný Albert Emil Kurt von Steiger-Münsingen von Rolle und Mont (1855-1918) pocházel z první linie. Ta od roku 1553 držela baronii Rolle, Montle-Vieux a Mont-le-Grand v dnešním kantonu Vaud (Waad). Počátkem 19. století Albertův děd Albrecht (1788-1866) ze Švýcarska odešel a stal se důstojníkem v britských a následně sicilských službách. Později podnikal v Čechách. Jeho syn Albert (1823-1893) spojil svou existenci také s rakouskou monarchií a žil převážně v Čechách, kde se oženil s Alexandrinou, hraběnkou von Zedtwitz (1827-1896). ${ }^{12}$

Albert Emil byl důstojníkem v záloze a získal také prestižní úřad c. a $\mathrm{k}$. komořího, jehož předpokladem byl starošlechtický původ z otcovy i matčiny strany. ${ }^{13}$ Velkostatek Hajná Nová Ves získal roku 1885 sňatkem s Marií Judith Eleonore Eugenií Ludmillou, hraběnkou Saryusz-Zamoyskou (1861-1926). Svou ženu, jež byla dvorní dámou na dvoře arcivévody Josefa, poznal během vojenské služby v rakousko-uherské armádě v Prešpurku. Majetek, který přinesla do manželství, původně patřil Ignáci Ocskayovi de Ocsko et Felsö Dubovan, jejímu dědovi z matčiny strany. ${ }^{14}$ Nepochybně i na základě svého majetkového vzestupu byl Albert von Steiger-Münsingen 5. prosince 1895 povýšen do uherského baronského stavu s predikátem de Roll et Monti (mad'. rolli és monti).$^{15} \mathrm{~S}$ rodinou často pobýval v Prešpurku (Bratislavě), kde Steinger-Münsingenové patřili k elitě zdejší společnosti. ${ }^{16}$

11 K rodu Schwarzenbergů srv. HORČIČKA, Václav. Die Schweiz und das Problem der Enteignung der Schwarzeberger Primogenitur in der Tschechoslowakei nach dem Zweiten Weltkrieg. In Schweizerische Zeitschrift für Geschichte, 2016, roč. 66, č. 1, s. 117-135. ISSN 0036-7834.

12 MAŠEK, Petr. Šlechtické rody v Čechách, na Moravě a ve Slezsku od Bílé hory do současnosti, dil II. (N-Ž). Praha: Argo, 2010, s. 306. ISBN 9788025702949.

13 Musel doložit 16 (tj. čtyři generace) šlechtických předků, po osmi z otcovy a matčiny strany. Srov. ŽUPANIČ, Jan. Nová šlechta Rakouského císařství. Praha: Agentura Pankrác, 2007, s. 30-31. ISBN 80867810809.

14 ZÁŇOVÁ, L'ubomíra. Pohrebná kaplnka rodiny Steiger. In Farské Listy, 2018, roč. 10, č. 35 [online]. Urmiance: Farský úrad RKC v Urmianciach, 2018, s. 8-9. Dostupné na internetu: $<$ https://www.farnosturmince.sk/wp-content/uploads/2018/04/FL35.pdf >. [cit. 2018-12-01].

15 Magyar Országos Levéltár, Budapest, Libri Regii - Királyi könyvek (dále MOL, LR), Bd. 69, fol. 926, 927-932.

16 Wiener Salonblatt, 11. 1. 1908, s. 5. 
Albertovi a Marii se narodily dvě děti - syn Albert (1887 - mezi 1907 a 1909), který ale zemřel velmi mladý, ${ }^{17}$ a dcera Maria Eugenia (1886-1976), jež se roku 1908 v Prešpurku provdala za Philippa Wilhelma hraběte von Walterskirchen (1866-1945), tehdy rytmistra husarského pluku č. 5, se kterým měla dva syny a výše zmíněnou dceru Marii (Marii Margarethu Iphigenii Barbaru). ${ }^{18}$ Nedlouho po sňatku, v prosinci 1908, získala i nejprestižnější dámský řád habsburské monarchie, Řád hvězdového křriže (Sternkreuzorden). ${ }^{19}$

Baron Albert zemřel nedlouho po rozpadu Rakousko-Uherska, 23. prosince 1918, na svém panství Hajná Nová Ves. Po jeho smrti převzala správu velkostatku manželka, a když i ona roku 1926 zemřela, ujala se správy většiny rodinného jmění dcera Marie Eugenie von Walterskirchen (1886-1976). Marie Eugenie se $\mathrm{v}$ roce 1925 se svým manželem, který byl československým občanem, rozvedla a získala tak zpět švýcarské občanství po otci. To jí po smrti matky umožnilo pokračovat $\mathrm{v}$ diskusích $\mathrm{s}$ československými úřady s podporou švýcarské diplomacie. ${ }^{20}$ Velkostatek Hajná Nová Ves (mad'. Hajnovejsa) se rozkládal v úrodné nížinaté oblasti západního Slovenska v povodí řeky Nitry nedaleko Topol’čian. Šlo spíše o menší velkostatek o rozloze 2602 katastrálních jiter (dále k. j.), tj. 1497 hektarů. ${ }^{21}$ Zemědělská půda tvořila téměř $70 \%$ velkostatku, necelých 20 \% pak lesy. Vedle toho rod vlastnil další, drobnějšś statky v sousedství o rozsahu přibližně $500 \mathrm{k}$. j.

Pozemkové vlastnictví švýcarských občanů v Československu zdaleka nedosahovalo významu majetku občanů rakouských či dokonce německých. To byla nesporně výhoda, protože vyřešit tyto, snad s výjimkou Geymüllerư ${ }^{22}$ spíše drobné kauzy, bylo z finančních a jiných důvodů pro Československo snazší, než ve výše uvedených př́padech. Ve prospěch švýcarských občanů pak dále hrála ochota Prahy přistupovat k požadavkům cizinců vstřícně. Není zde dostatek prostoru zabývat se tímto aspektem pozemkové reformy obsáhleji, přesto je však nutné věnovat mu jistou pozornost. Je zřejmé, že Praha postupovala vstřícně zejména vůči občanům velmocí tzv. Dohody (Entente). Např́íklad britské vyslanectví $\mathrm{v}$ Praze velmi čile $\mathrm{v}$ těchto prípadech intervenovalo a vymohlo poddaným

17 Důvod není znám. V tzv. Gothajském almanachu z roku 1905 uveden ještě je, v roce 1909, ale již nikoli. Gothaisches Genealogisches Taschenbuch der Freiherrlichen Häuser, Gotha 1905, s. 772 a 1909 , s. 800.

18 Wiener Salonblatt, 19. 9. 1908, s. 13; Gothaisches Genealogisches Taschenbuch der Gräflichen Häuser, Gotha 1920, s. 1038-1040.

19 Wiener Zeitung, 13. 12. 1908, s. 1.

20 BAR, Bestand E 2200.190-03, Akzession 1000/318, Behältnis 8, Eidgenössisches Justiz- und Polizeidepartment, Wiederaufnahme in das Schweizerbürgerrecht, 30. 12. 1926, No. 272.

211 české katastrální jitro $=0,5557$ ha.

22 Bratři Georg a Richard von Geymüllerové vlastnili v jižních Čechách velkostatek Kamenici nad Lipou o rozloze zhruba 5500 ha. 
Jeho britského Veličenstva velkorysé provedení pozemkové reformy zejména v oblasti náhrady za vyvlastněný majetek. Státní pozemkový úřad (SPÚ) přiznával, že ,od počátku [provádění reformy - V. H. - J. Ž.] byl si vědom potřeby neb taktičnosti toho, aby byl brán na ně (přislušníky spojeneckých státì-pozn. aut.) zřetel... "23. I díky tomu, že vlastníků s britským pasem nebylo mnoho, vyšly jim československé úřady dalekosáhle vstříc. ${ }^{24}$

Ale i ve vztahu k Německu bylo Československo ochotno ke koncesím. Obávalo se totiž žalob německých občanů u smíšeného československo-německého rozhodčího soudu, který byl zřízen na základě článku 304 Versailleské mírové smlouvy. Přistoupilo proto na separátní jednání s německou vládou o vyřešení pozemkové reformy, přičemž ústupky činilo zejména $\mathrm{v}$ oblasti náhrady za vyvlastněnou a státem převzatou půdu. Vedle toho byla Praha ochotna snížit vyměřené majetkové dávky, které německá vláda ve spojení s pozemkovou reformou považovala za faktickou konfiskaci majetku. ${ }^{25}$ Berlín přitom uznával, že Československo má právo vyvlastnit pozemkový majetek cizinců, požadoval však za něj, podobně jako např. britská vláda, přiměřenou náhradu. ${ }^{26}$ Byl tak vytvořen prostor pro smírné vyřešení problému.

Nejistota československých úřadů, zda je možné pozemkovou reformu beze zbytku v cizině obhájit, je zjevná především z jejich interních materiálů. Provedením reformy pověřený Státní pozemkový úřad (SPÚ) upozorňoval v listopadu 1924 ministerstvo zemědělství, že spolu s Černínským palácem (ministerstvem zahraničních věcí) čelí ,, pochybnostem ciziny o správnosti principư naší pozemkové reformy “. Připouštěl, že některé výtky jsou oprávněné. Uznával například, že přejímací ceny jsou nízké a přiznával pochybnosti o odkladech vyplacení náhrad (část pohledávky se zaznamenala $\mathrm{v}$ tzv. náhradové knize, byla zúročena

23 Archiv ministerstva zahraničních věcí České republiky (dále AMZV), fond VI. sekce právní 1918-1945 (dále VI. sekce), předseda státního pozemkového úřadu Viškovský právní sekci čsl. ministerstva zahraničních věcí, kt. 505, 12. 10. 1921, No. K č. j. 23.460.

24 Jednalo se především o barona Maurice de Foresta (původně svobodného pána von Deforest-Bischoffsheim) s majetkem na Moravě (Rosice-Veveří) a sira Williama Garthwaita na Slovensku (Pruské, okr. Iĺava). Striktněji se postupovalo jen vůči Agathe Whiteheadové a to zejména proto, že poz. reformou dotčený velkostatek Želiezovce na Slovensku měl více vlastníků s různým občanstvím. Srov. HANULA, Matej. Hl'adanie priatel'ského kompromisu: realizácia československej pozemkovej reformy na majetkoch britských občanov s dôrazom na Slovensko. In KOVÁČ, Dušan. Slovenské dejiny v dejinách Európy. Vybrané kapitoly. Bratislava: Historický ústav SAV; Veda, 2015, s. 136-154; ŽUPANIČ, Jan. Der Erbe des Barons von Hirsch. Maurice Arnold Freiherr von Deforest-Bischoffsheim. Das vergessene Schicksal des Grafen von Bendern. In Historischer Verein für das Fürstentum Liechtenstein. Jahrbuch, Bd. 110, 2011, s. 47-61. ISBN 9783906393506.

25 Šlo o dávku z majetku a o dávku z přírůstku na majetku.

26 AMZV, VI. sekce, kt. 181, Vondruška (SBA), Memorandum o pozemkové reformě na majetku německých státních př́slušníků, 8. 2. 1938, No. K č. j. 165.518/38-IX/22. 
a postupně splácena). Bylo je však „obtížně, ale přece“ možné vysvětlit poukazem na to, že ceny půdy po válce opět poklesly, a že se majitelé velkostatků díky válečné inflaci snadno zbavili všech dluhů. Ještě diskutabilnější byla podle SPÚ vymáhaná dávka z majetku a z př́růstku na majetku za týž majetek, který byl státem vlastníku odebírán. Vlastník navíc musel platit hned a hotově, zatímco stát za půdu platil většinou jen s odklady skrze náhradovou banku. Státní pozemkový úřad uznával, že dávkou zatížený majetek ,,v době splatnosti dávky někdy již neexistuje“. Podle jeho názoru toto nebylo možné ,nijak vysvětliti a nijak oduivodniti “. ${ }^{27}$

Výše náhrad za vyvlastněnou půdu tedy byla ve spojení s majetkovými dávkami cizími vládami kritizována nejvíce. Šlo ovšem o komplikovaný problém. Na jednu stranu totiž SPÚ v roce 1924 přiznával, že skutečná, tržní cena vyvlastňovaných velkostatků je 2-3 krát vyšší než přiznaná náhrada. Upozorňoval však na to, že velkostatky byly před válkou silně zadluženy. Domníval se, že kdyby nebylo pozemkové reformy, došlo by po válce $\mathrm{k}$ jejich masivním odprodejům a tržní ceny by byly ještě výrazně nižší. ${ }^{28}$ Ovlivnit výši náhrad se s různým úspěchem pokoušeli všichni vyslanci zainteresovaných států. Mezi méně úspěšné patřili např́íklad rakouští diplomaté. Bylo tomu tak proto, že Rakousko podobně jako Německo nechtělo kvůli sporu o pozemkovou reformu riskovat konflikt s Československem. ${ }^{29}$ Navíc samo po válce, byt' v podstatně menším rozměru, půdu vyvlastňovalo a obávalo se, že na to bude Praha poukazovat. ${ }^{30}$ Československé ministerstvo zahraničních věcí přitom dospělo na sklonku roku 1929 k závěru, že přiznaná náhrada za všechny Rakušanům vyvlastněné velkostatky dosahuje zhruba poloviny aktuální tržní ceny půdy. ${ }^{31} \mathrm{~V}$ této době však začala

27 Státní oblastní archiv Třeboň, oddělení Český Krumlov, fond Schwarzenberské ústřední ředitelství Hluboká nad Vltavou 1905-1944, kt. 91, SPÚ (Viškovský) ministerstvu zemědělství (př́sně důvěrné), 11. 11. 1924, No.: Čís. 74027/24-I/1.

28 AMZV, VI. sekce, kt. 187, Posudek odhadního odboru Bodenamtu, 21. 8. 1924, No. K. č. j. Sp 23/24-360, 363/24.

29 Rakouská diplomacie interně uznávala, že její pozici oslabuje fakt, že se reforma týká i československých občanů a nechtěla proto postupovat podle St. Germainské mírové smlouvy, což ji navrhovali postižení rakouští velkostatkáři. ÖStA, AdR, Ges. Prag, kt. 63, Peter (generální sekretár̆ für AA) Markovi (rak. vyslanec v Praze), 9. 12. 1929, No. Z. 188.035 - 14a.

30 ÖStA, AdR, Ges. Prag, kt. 63, Bundeskanzleramt - Auswärtige Angelegenheiten Markovi, 10. 1. 1925, No. 215/Res. Vyvlastnění bylo prováděno na základě tzv. Wiederbesiedlungsgesetz z 31. 5. 1919. Dostupné na internetu: < http://alex.onb.ac.at/cgi-content/alex?aid=sgb\&datum $=1919 \&$ page $=815 \&$ size $=45>$. [cit. 2018-12-01].

31 Zatímco průměrnou tržní cenu odhadovalo ministerstvo zahraniční na 3 500,- Kčs za hektar, průměrná náhrada dosahovala 1800 ,- Kčs a výrazně se tak nelišila od náhrady vyplácené československým občanům. Údaj měl značnou vypovídací hodnotu, protože Rakušanům bylo do té doby vyvlastněno 131979 ha půdy. AMZV, VI. sekce, kt. 510, Úřední záznam, 31. 12. 1929, No. K. č. j. 166.448/29-Z. 
Velká hospodářská krize, která způsobila pokles cen půdy a vyplácená náhrada se tak ještě více přiblížila skutečné tržní ceně.

Švýcarsko se při obhajobě zájmů svých občanů soustředilo podobně jako výše uvedené státy na právně nejsnáze napadnutelné aspekty reformy. Uznávalo právo Československa vyvlastnit půdu na svém území, avšak za přiměřenou náhradu. ${ }^{32}$ Nemalou komplikaci ve snahách dosáhnout pro své občany patřičné kompenzace představovala skutečnost, že Švýcarsko nemělo v Praze řádné diplomatické zastoupení. Jeho zájmy zde reprezentoval jen honorární generální konzul Gérold Déteindre, shodou okolností vlastník spíše menšího velkostatku v Čechách. ${ }^{33}$ Déteindre byl přes svou majetkovou zainteresovanost ve věci provádění pozemkové reformy jako reprezentant švýcarských zájmů poměrně pasivní. Kriticky to vnímali i jeho nadřízení. Např́klad na sklonku roku 1926 byl centrálou vyzván, aby zlepšil zpravodajskou činnost. ${ }^{34}$ Změnu k lepšímu však přineslo až zř́zení stálého diplomatického zastoupení v roce 1927.

Paní von Steiger se s ohledem na pozemkovou reformu potýkala s obdobnými problémy jako Déteindre a další švýcarští vlastníci. Šlo zejména o to, kolik půdy bude nutné obětovat a dále o výši náhrad. $V$ jejím př́ípadě věc dále komplikovalo ne zcela vyjasněné vlastnictví velkostatku, resp. dispoziční práva k němu, ve kterém se zcela neorientovala ani pražská centrála SPÚ. Již před smrtí Alberta von Steigera v prosinci 1918 si manželé sami vlastnictví velkostatku Hajná Nová Ves rozdělili. ${ }^{35}$ Po Albertově smrti navíc získala část velkostatku (asi 500 jiter) jeho dcera hraběnka Marie von Walterskirchen, čímž vznikl samostatný velkostatek Kamanová. ${ }^{36}$

Zmenšený velkostatek Hajná Nová Ves byl kromě toho v roce 1919, tedy ještě za života Marie von Steiger, rozdělen na dvě přibližně stejné části. První si v podstatě se všemi lesy (jen asi 200 ha) ponechala Marie, zbývající část skládající se téměř výlučně ze zemědělské půdy, měla být předána jejím nezletilým vnukưm Maxmiliánovi, Krištofovi a Margitě, dětem dcery Marie Eugenie, provdané hraběnky von Walterskirchen. ${ }^{37}$ Baronka Steigerová si přitom k těmto

32 BAR, Bestand E 2001 C, Akzession 1000/1531, Behältnis 97, EPD Déteindremu, 11. 6. 1924, No. C 42/111/1 Tsch.-HI.

33 Šlo o velkostatek Stekník-Štěrkovice nedaleko Žatce o rozloze necelých 500 ha.

34 BAR, Bestand E 2001 C, Akzession 1000/1531, Behältnis 97, EPD Déteindremu, 24. 12. 1926, No. C 42 Tsch. - ML.

35 BAR, Bestand E 2200.190-03, Akzession 1000/318, Behältnis 8, Déteindre, Verzeichnis über das Vermögenstand des Herrn B. Albert Steiger und der Frau B. Steiger, geb. Gr. Marie Zamoyska, 25. 8. 1919, No. chybí.

36 Slovenský národný archív (SNA), fond ŠPÚ Praha (ŠPÚ), L 1757 (vel'kostatok Hanovejsa), Šk. 2412, Státní přídělový komisař v Nitře Ministerstvu zemědělství, 13. 6. 1936, No. č. j. 3436/36.,

37 SNA, ŠPÚ, L 1757, Šk. 2415, Darovací smlouva, 27. 5. 1919. 
polnostem ponechala uživatelské právo. ${ }^{38}$ Tato transakce ale nebyla schválena SPÚ. Další dělení velkostatku by totiž znamenalo snížení plochy zemědělské půdy, kterou bylo možné přidělit novým nabyvatelům. ${ }^{39}$ Se státem tak vyjednávala o budoucnosti celého velkostatku Hajná Nová Ves sama. Vedle výše uvedeného majetku vlastnila ještě paní von Steiger společně se svou sestrou Ludmilou Zamoyskou rovným dílem dvůr Lehota (Aba Lehota). ${ }^{40}$ Dvůr byl původně součástí velkostatku Brestovany, který patřil Zamoyským. ${ }^{41}$

V roce 1924 se paní von Steiger dohodla (ovšem pod tlakem) s SPÚ na odevzdání 279 katastrálních jiter půdy z velkostatku Hajná Nová Ves ${ }^{42} \mathrm{~s}$ přejímací cenou ve výši téměř 198000 korun, tedy necelých 1300 Kč za hektar. ${ }^{43}$ Navíc jí bylo vyvlastněno dalších zhruba $150 \mathrm{k}$. j. za jen mírně vyšší náhradu. ${ }^{44}$ Statek Lehota pak byl na podzim téhož roku $z$ větší části rozdělen na jednotlivé př́íděly, z menší části byl utvořen zbytkový statek..$^{45}$ Vlastníkům ovšem nebylo umožněno prodat zbytkový statek z volné ruky, nového nabyvatele určil SPÚ. ${ }^{46}$ Za vyvlastněnou půdu o rozsahu $292 \mathrm{k}$. j. pak vlastnice získaly náhradu ve výši zhruba 325000 Kč. ${ }^{47}$ Náhrada byla při přepočtu na plochu výrazně vyšší než v př́padě Hajné Nové Vsi. Důvody nejsou z dokumentace zřejmé. Snad tomu bylo tak proto, že SPÚ získal celý velkostatek. $\mathrm{V}$ těchto případech bývali původní vlastníci bonifikováni.

V roce 1925 pak SPÚ sice propustil podle $\S 11$ záborového zákona ze záboru celkem 611 k. j. půdy, ${ }^{48}$ požadoval ale dalších více než 200 katastrálních jiter, $\mathrm{k}$ tzv. prodeji z volné ruky. ${ }^{49}$ Tuto půdu tedy stát př́mo nevyvlastnil, ale nařídil

38 BAR, Bestand E2200.190-03, Akzession 1000/318, Behältnis 8, Grundbesitz der Frau Br. Marie Steiger-Zamoyska in der čechoslov. Republik, bez data (počátek roku 1924). Šlo Maximiliana, Christopha a Margarethe Walterskirchen.

39 SNA, fond Štátna obvodná úřadovna Bratislava, L 1757, Šk 570, SPÚ Turchányimu (advokát Marie von Steiger) a Marii von Walterskirchen, 13. 6. 1925, No. 59.978/24-I/4.

40 SNA, fond Štátna obvodová úradovňa Bratislava, L 1757, Šk 570, Obvodová úradovňa štátneho pozemkového úradu v Trenčíně SPÚ, 10. 7. 1926, No. 6224/26.

41 NA, SPÚ-VŠ, kt. 334, SPÚ min. zahraničních věcí, 30. 8. 1928, No. 101.772/28-Z.

42 AMZV, VI. sekce, kt. 508, SPÚ min. zahraničních věcí, 30. 8. 1928, No. 101.772/28 - Z.

43 SNA, ŠPÚ, L 1757, Šk. 2412, SPÚ, Rozhodnutí, 5. 11. 1924, No. č. j. 98.523/24-II/4.

44 SNA, ŠPÚ, L 1757, Šk 2413, Ministerstvo zemědělství, Přednosta III. skupiny Přednostovi IX. odboru, 19. 6. 1936, No. chybí.

45 SNA, ŠPÚ, L 1933 (vel'kostatok Lehota), Šk. 2731, Ministerstvo zemědělství, Úřrední připomínka, 14. 2. 1936, No. 148969/IX-V/4/1936.

46 SNA, ŠPÚ, L 1933, Šk. 2731, Obvodová úradovňa Trenčín centrále SPÚ, 16. 9. 1925, No. 10413/25. I.

47 SNA, ŠPÚ, L 1933, Šk 2729, SPÚ, Dohoda o přejímací ceně a náhradě za strojená hnojiva, 4. 11. 1924, No. č. j. 98519/24-II/4.

48 SNA, ŠPÚ, L 1875, Šk. 2415, SPÚ Turchányimu, 8. 7. 1925, No. Č. j. 80.751/25-II/4.

49 AMZV, VI. sekce, kt. 508, SPÚ min. zahraničních věcí, 30. 8. 1928, No. 101.772/28 - Z. 
její prodej určeným nabyvatelům. Státní pozemkový úřad přitom údajně hrozil, že pokud nevyhoví, neponechá majitelce ani zákonem předpokládanou maximální povolenou výměru. ${ }^{50}$ Zde je třeba konstatovat, že př́ídělový zákon umožňoval v $§ 20 \mathrm{~s}$ odvoláním na zájem ochrany památek a př́rodních krás ponechat velkostatkár̆ům mnohem více půdy, než bylo oficiálně stanovené maximum dle $\S \S 3$ a zejména 11 záborového zákona. ${ }^{51}$

V této situaci se na švýcarské úrada obrátil jeden z právních zástupců Marie Steigerové, známý pražský advokát Franz Wien-Claudi. Tento specialista vedl souběžně řadu kauz spojených s pozemkovou reformou. Zastupoval zejména vlastníky německého jazyka s různou státní prríslušností. Ve svých požadavcích byl velmi houževnatý a málo nakloněn kompromisu s československým státem. Advokátovo podání do Bernu dorazilo v březnu 1925, tedy krátce poté, co již švýcarské ministerstvo zahraničních věcí neboli Politický departement (Eidgenössisches Politisches Departement, EPD) provedlo intervenci ve prospěch jiných švýcarských vlastníků. Švýcarsko proto zásah ve věci baronky von Steiger prozatím odmítlo a vyčkávalo na odpověd' ve výše uvedené záležitosti. Ve sdělení generálnímu konzulovi Déteindremu ovšem EPD zmínil ještě jeden důvod svého váhání aktivně vystoupit. Bylo jím rakouské občanství vnuků baronky von Steiger. ${ }^{52}$ Bern totiž obecně k hájení zájmů svých občanů s dvojím občanstvím prristupoval vlažně. Po v zásadě vstřícné odpovědi ze švýcarské metropole se v listopadu a prosinci 1925 dostala záležitost paní von Steiger přesto znovu do pohybu.

Wien-Claudi v novém podání EPD tvrdil, že jeho klientka má podle mezinárodního práva nárok na plné odškodnění za vyvlastněný majetek. Požadoval, aby Švýcarsko „energicky“ diplomaticky zasáhlo a vymohlo plnou náhradu, a aby dosáhlo zastavení dalšího vyvlastňování. Pokud by se tak nastalo, měl Bern podle názoru advokáta záležitost předat mezinárodní arbitráži. ${ }^{53}$ Vůči těmto návrhům byl ovšem skeptický generální konzul Déteindre, který paní von Steiger informoval, že pozemková reforma probíhá i na jeho velkostatku. Soudil, že ji nelze zastavit, nanejvýš snad dosáhnout zvýšení odškodného. Sliby SPÚ

50 BAR, Bestand E2200.190-03, Akzession 1000/318, Behältnis 8, Wien-Claudi EPD, 16. 11.1925.

51 Zákon ze dne 30. 1. 1920, kterým se vydávají po rozumu §u 10 Zákona ze dne 16. dubna 1919, č. 215 Sb. zák. a nař., ustanovení o prŕídělu zabrané půdy a upravuje se právní poměr ku předělené půdě. (Zákon př́ídělový), č. 81, Sb. zák. a nařízení. Dostupné na internetu: $<$ https://www.epravo.cz/vyhledavani-aspi/?Id=1661\&Section=1\&IdPara=1\&ParaC=2>. [cit. 2018-12-01].

52 BAR, Bestand E2200.190-03, Akzession 1000/318, Behältnis 8, EPD Déteindremu, 2. 4. 1925 , No. C 42 Tsch.-KL.

53 BAR, Bestand E2200.190-03, Akzession 1000/318, Behältnis 8, Wien-Claudi EPD, 18. 12. 1925. 
prý neměly „,vůbec žádnou cenu“. Důvěrně pak paní von Steiger sděloval, že se pokusil zainteresovat na osudu krajanů v Československu švýcarský tisk. ${ }^{54}$ Takový postup nebyl u švýcarského konzula právě obvyklý, a pokud se o něm v Bernu dozvěděli, jistě přispěl k rozhodnutí o ukončení Déteindrovy mise.

Na počátku roku 1926 se situace zdramatizovala natolik, že EPD nezbylo než zasáhnout. Na jednání mezi zástupci SPÚ, velkostatku a zájemců o př́iěl další půdy totiž nedošlo $\mathrm{k}$ dohodě. Rolníci se pak údajně na radu místních předáků agrární strany rozhodli svévolně ujmout nárokovaných pozemků. Wien-Claudi proto žádal švýcarský generální konzulát v Praze, aby zapůsobil na československou vládu, aby vynutila návrat zabraných pozemků velkostatku. ${ }^{55}$ Nešlo přitom o jen o drobná políčka, ale o zásadní část velkostatku o rozloze 392 kat. jiter. ${ }^{56}$ Než stačil Déteindre ve věci vůbec zaujmout stanovisko, přidělil SPÚ obsazenou půdu, aniž dal předtím, jak zákon vyžadoval, velkostatku výpověd' z hospodaření, osobám, které se jí zmocnily. Není divu, že Wien-Claudi proti tomuto výnosu opět protestoval a požadoval, aby SPÚ své rozhodnutí o př́iělu zrušil. ${ }^{57}$ Na jednání v pražské centrále SPÚ prakticky ve stejné době nedošlo k dohodě o náhradové ceně za již vyvlastěnou půdu o rozloze více než 600 katastrálních jiter. Baronka sice uznala, že nabízená přejímací cena ve výši necelých 240 tis. Kčs odpovídá náhradovému zákonu, odvolala se však na své švýcarské občanství a požadovala plnou náhradu ve výši 5 000,- Kčs za hektar. ${ }^{58} \mathrm{~V}$ dubnu 1926 pak SPÚ baronce údajně vyhrožoval, že pokud se přidělené půdy dobrovolně nevzdá, bude jí ponecháno jen zákonné maximum rozlohy velkostatku. ${ }^{59}$ Podle Wien-Claudiho šlo ,o ve zdejším kraji tak oblibený teroristický čin podřizených orgánů... “, o kterém nebyla pražská centrála SPÚ informována.

Déteindre mezitím jednal o provádění pozemkové reformy na EPD v Bernu. Bylo mu zde řečeno, že ,nemůžeme ovlivňovat vyvlastňování, protože nám nepřisluši zpochybňovat přijaté zákony... “. EPD však byl ochoten zasadit se o vyšší odškodné a zaslat do Prahy př́slušnou nótu. ${ }^{60}$ Ta byla předána 4 . května

54 BAR, Bestand E2200.190-03, Akzession 1000/318, Behältnis 8, Déteindre von Steiger, 16. 12. 1925 , No. $5809 / \mathrm{C}$.

55 BAR, Bestand E2200.190-03, Akzession 1000/318, Behältnis 8, Wien-Claudi švýc. generálnímu konzulátu, 5. 3. 1926.

56 Podle jiných zdrojů šlo o 337 kat. jiter. AMZV, VI. sekce, Informace, bez data, zřejmě 1937.

57 BAR, Bestand E2200.190-03, Akzession 1000/318, Behältnis 8, Wien-Claudi švýc. generálnímu konzulátu, 15. 3. 1926.

58 BAR, Bestand E2200.190-03, Akzession 1000/318, Behältnis 8, SPÚ, Protokoll, 17. 2. 1926, No. chybí.

59 BAR, Bestand E2200.190-03, Akzession 1000/318, Behältnis 8, Wien Claudi Déteindrovi, 20. 4. 1926.

60 BAR, Bestand E2200.190-03, Akzession 1000/318, Behältnis 8, Déteindre von Steiger, 24. 3. 1926. 
$1926 .{ }^{61} \mathrm{~V}$ odpovědi z 2 . července 1926 československé ministerstvo zahraničních věcí k velké nespokojenosti Wien-Claudiho a jeho mandantky tvrdilo, že švýcarští občané nemají nárok na vyšší odškodnění než občané českoslovenští a podléhají náhradovému zákonu. Advokát pak s odvoláním na mezinárodní právo obsáhle vyvozoval, že tomu tak není a žádal Bern, aby trval na plném odškodnění, v opačném př́ípadě znovu doporučoval obrátit se na mezinárodní arbitráž. ${ }^{62}$ Je s podivem, že Déteindre odpověd' nezaslal okamžitě do Bernu, EPD si ji musel zvlášst vyžádat. ${ }^{63}$ Svědčí to opět o jeho nekonformních pracovních metodách.

V létě a na podzim 1926 tak situace pro švýcarské velkostatkáře nevypadala příznivě. Marie von Steiger sice dosáhla v červenci 1926 během osobního jednání na místě dohody s SPÚ o vyřešení pozemkové reformy. Státní pozemkový úrad slíbil ze záboru propustit zbývající půdu a dokonce podle $\S 11$ záborového zákona dalších asi 55 kat. jiter, která původně zamýšlel vyvlastnit. Majitelka si ale vyhradila právo požadovat náhradu ve výši přiznané event. v budoucnosti cizincům. ${ }^{64}$ Př́itomní svědkové jednání později potvrdili, že byl na ní údajně ze strany zástupců SPÚ vyvíjen nepř́pustný nátlak. ${ }^{65} \mathrm{~V}$ listopadu 1926 SPÚ svou část dohody splnil. Propustil ze záboru výše uvedených $55 \mathrm{k}$. j., podle $§ 20$ př́iělového zákona navíc uvolnil 437 k. j. ${ }^{66}$

V polovině prosince 1926 zemřela baronka von Steiger, dědičkou byla její dcera Marie Eugenie. Bern byl kvưli Déteindrově laxnosti celý podzim 1926 bez informací. Přitom švýcarští diplomaté považovali za nutné co nejdřive odpovědět na červencovou československou nótu. Navíc v říjnu 1926 SPÚ převzal dalších více než 330 kat. jiter půdy. ${ }^{67}$ Podle výkazů SPÚ bylo v roce 1926 celkem převzato 709 katastrálních jiter půdy. ${ }^{68} \mathrm{Na}$ sklonku roku 1926 EPD opět Déteindra žádal o dodatečné informace o situaci, včetně situace politické a konzul měl zaujmout stanovisko i k př́padům ostatních dotčených švýcarských velkostatkářo̊ ${ }^{69}$ Zájem Bernu o politickou situaci byl pochopitelný, protože v ř́ijnu 1926 v Praze vznikla vláda tzv. panské koalice.

61 AMZV, VI. sekce, kt. 508, Déteindre čsl. min. zahraničních věcí, 4. 5. 1926, No. 1620.

62 BAR, Bestand E2200.190-03, Akzession 1000/318, Behältnis 8, Wien-Claudi EPD, 23. 8. 1926.

63 BAR, Bestand E2200.190-03, Akzession 1000/318, Behältnis 8 Déteindre EPD, 13. 8. 1926. Déteindre se prý domníval, že kopie nóty byla již EPD odevzdána československým vyslanectvím v Bernu.

64 AMZV, VI. sekce, kt. 508, Vereinbarung bezüglich der Übernahme ohne Kündigung, 30. 7. 1926, No. chybí.

65 AMZV, VI. sekce, kt. 508, Weiss, Osvedčenie, 17. 11. 1931.

66 SNA, ŠPÚ, L 1875, Šk. 2415, SPÚ Marii von Steiger, 18. 11. 1926, No. Čj. 89.396/26-II/4.

67 AMZV, VI. sekce, Kt. 508, Informace, bez data, zřejmě 1937.

68 AMZV, VI. sekte, kt. 508, SPÚ ministerstvu zahr. věcí, 30. 8. 1928, No. 101.772/ 28 - Z.

69 BAR, Bestand E2200.190-03, Akzession 1000/318, Behältnis 8, EPD Déteindremu. 
Déteindre soudil, že SPÚ je ve vztahu k cizincům ve „slepé uličce,“ protože má obavu z internacionalizace sporu s německými a rakouskými vlastníky velkostatkủ. Chtěl by proto vyjít těmto vstř́c, ale nedisponuje $\mathrm{k}$ tomu dostatečnými finančními prostředky. Tato informace se, jak už bylo ukázáno v úvodu tohoto článku, v zásadě zakládala na pravdě. Pokud jde o dědictví po baronce von Steiger, hlásil, že se její dcera už od roku 1925 rozvádí s hrabětem Philippem Wilhelmem von Walterskirchen a požádala o navrácení švýcarského občanství (tzv. Wiedereinbürgerung). ${ }^{70}$

Déteindreho informace nebyly zcela přesné, protože kanton Bern hraběnce občanství vrátil již srpnu 1926, tedy ještě před smrtí její matky. ${ }^{71}$ EPD tedy nezbylo, než její př́pad dále sledovat. Hraběnka si celkem rozumně najala nového advokáta ve Švýcarsku a požádala EPD, aby se zasadil o zvýšení náhrady za dosud vyvlastněných téměř 700 ha půdy. Realisticky uznávala, že návrat státem vyvlastněného majetku zpět do vlastnictví rodiny není pravděpodobný. ${ }^{72}$

V této neprŕliš nadějné situaci do věci výrazně zasáhla změna ve vedení švýcarské diplomatické mise v Praze. Bylo zde zřízeno vyslanectví, jeho šéfem však byl od července 1927 až do prosince 1936 vyslanec v Polsku. Vyslanec HansAlbrecht de Segesser navštívil Prahu v září 1927 a během svého krátkého pobytu jednal na československém ministerstvu zahraničí také o pozemkové reformě. Bylo mu sice řečeno, že SPÚ přistupuje k cizincům stejně, jako k československým občanům, tomuto vyjádření však titulář nepřikládal velký význam. Měl totiž k dispozici důvěryhodné, avšak bohužel pro švýcarské velkostatkáře jen neoficiální informace, že zejména britští občané byli velkoryse odškodněni. ${ }^{73}$ Vzhledem k nedostatku důkazů nemohl žádat stejné odškodnění, upozorňoval tedy proto alespoň na fakt, že pozemkovou reformou postižených Švýcarů je velmi málo a neměl by být tedy problém jim vyjít vstř́c. Praha ovšem nehodlala postupovat tak velkoryse, jako v prrípadě Britů. Vyslanec Kamil Krofta de Segesserovi ne zcela v souladu se skutečností tvrdil, že ministerstvo zahraničí, ba dokonce celá československá vláda, nemají na SPÚ př́liš velký vliv. ${ }^{74}$

24. 12. 1926, No. C 42 Tsch. -ML.

70 BAR, Bestand E2200.190-03, Akzession 1000/318, Behältnis 8, Déteindre EPD, 5. 1. 1927.

71 BAR, Bestand E2200.190-03, Akzession 1000/318, Behältnis 8, W. von Steiger EPD, 19. 5. 1927.

72 Tamtéž. Hraběnku nově zastupoval W. von Steiger z Bernu.

73 K tomu též HANULA, ref. 24. Dále DUFEK, Pavel. Zaměstnanci Státního pozemkového úřadu v „minovém poli“ zahraniční politiky a pastích politiky domáci - př́ípadová studie. In RAŠTICOVÁ, Blanka (ed.). Agrární strany ve vládních a samosprávných strukturách mezi světovými válkami. Studie Slováckého muzea, 13, Uherské Hradiště, 2008, s. 162-165. ISBN 9788086185729.

74 BAR, Bestand E 2001 C, Akzession 1000/1531, Behältnis 97, Segasser EPD, 19. 9. 1927, No. $3535 /$. 
Místo de Segessera, který sídlil ve Varšavě, fakticky vedl pražskou misi chargé d'affaires Karl Bruggmann. Od podzimu 1927 opakovaně jednal v záležitosti paní von Walterskirchen i dalších reformou postižených Švýcarů na československém ministerstvu zahraničních věcí. Byl skeptický k možnosti dotlačit Prahu novými oficiálními intervencemi $\mathrm{k}$ dalším ústupkům. Místo toho chtěl sám př́mo vyjednávat s SPÚ a kauzy ukončit výhodným kompromisem. Kritizoval př́stup právních zástupců švýcarských velkostatkářů v Československu. Domníval se totiž, že by se švýcarští občané měli vzdát polemik s postojem úruadů a místo toho se s nimi „co možná nejnenápadněji“ dohodnout. ${ }^{75}$ Stejně otevřeně sdělil Bruggmann svůj postoj úředníkům československého ministerstva zahraničních věci. Podle př́íslušného záznamu zde uznal, že švýcarští vlastníci dosud s SPÚ vyjednávali nevhodným způsobem, ,,tj. misto aby se hleděli s ním dohodnouti o způsobu provedeni pozemkové reformy, zasypávali SPÚ podáními advokátù (většinou berlinských), v nichž se operovalo hlavně mezinárodním právem " ${ }^{76}$ Ministerstvo zahraničních věcí pak Bruggmannovi dohodlo audienci u prezidenta SPÚ a umožnilo zahájit přímá jednání. ${ }^{77}$ Voženílek byl v zásadě ochoten vyjít Švýcarům vstříc, obával se ale, aby mírný postup SPÚ vůči nim se nestal precedentem $\mathrm{v}$ případech jiných postižených velkostatkářů cizí státní príslušnosti. $^{78}$

Po zrrízení švýcarského vyslanectví v Praze nabyl i případ Hajná Nová Ves vyšší dynamiku. Vyslanectví bylo v listopadu 1927 stručně, ale výstižně informováno o aktuální situaci. Jak již bylo uvedeno, kromě velkostatku Hajná Nová Ves hraběnka Walterskirchenová vlastnila ještě po smrti otce získané zboží Kamanová, které leželo nedaleko prvně jmenovaného velkostatku. Spolu s přilehlou částí Kamanové, která původně zůstala její matce, a kterou po její smrti zdědila, měl tento velkostatek rozsah téměř 800 jiter. Téměř polovina této plochy byla rozparcelována. ${ }^{79}$ Náhrada ještě nebyla stanovena, ale počítalo se s pouhými 1400 Kč za hektar, skutečná hodnota byla majitelkou odhadována na 8-14 tis. Kčs. Z velkostatku Hajná Nová Ves zbývalo v roce 1927 jen asi 1400 jiter, tedy jen o něco málo více, než polovina původní rozlohy. Náhrada byla v tomto případě již částečně určena, pohybovala se mezi 900-1 400 Kčs za hektar. ${ }^{80}$

75 BAR, Bestand E 2001 C, Akzession 1000/1531, Behältnis 97, Bruggmann EPD, 5. 11. 1927, No. 3894.

76 AMZV, VI. sekce, kt. 505, Pro domo, 4. 11. 1927.

77 Tamtéž.

78 BAR, Bestand E 2001 C, Akzession 1000/1531, Behältnis 97, EPD Bruggmannovi, 14. 12. 1927, No. C 42 Tschech. - OC.

79 SNA, ŠPÚ, L 1757, Šk. 2413, Stav pozemkového majetku rodiny Steiger Zamoyský pred a po pozemkovej reforme, bez data (asi 1935).

80 BAR, Bestand E2200.190-03, Akzession 1000/318, Behältnis 8, Turchányi švýc. vyslanectví Praha, 14. 11. 1927 
Ani paní von Walterskirchen ovšem nenásledovala rady chargé d'affaires Bruggmanna bez výhrad. Zdráhala se zejména najmout si v Praze českého advokáta. Váhání odůvodňovala vysokými náklady a př́ípad chtěla ř́́dit z Bernu, kamž se přestěhovala ${ }^{81}$ Bruggmann ovšem i přesto dosáhl na SPÚ slibu vyšší náhrady za pozemky, kde ještě nebyla stanovena. ${ }^{82}$ Jednání se ovšem vleklo, hraběnka na EPD opakovaně vymáhala zvýšení náhrady na sedminásobek přiznané úrovně a tam, kde ještě nebyla určena, pak její stanovení na úrovni aktuální tržní ceny. ${ }^{83}$ Celkem se hraběnka domáhala jen na velkostatku Hajná Nová Ves zhruba 7 milionů korun, přiznáno jí zatím SPÚ bylo necelých 200 000. Vedle toho dodatečně žádala i vyšší náhradu za velkostatek Lehota, který její matka vlastnila společně se svou sestrou Ludmilou Zamoyskou. ${ }^{84}$

Situace se zatím nevyvíjela dobře. Švýcarské vyslanectví se sice 11. května 1928 znovu obrátilo na československé ministerstvo zahraničních věcí se žádostí o vstř́cnost vůči požadavkům paní von Steiger, ta však čelila kvůli nezaplaceným daním riziku exekuce. Její advokáti evidentně nebyli schopni věc kompetentně řšit, takže si chargé d'affaires Bruggmann dokonce vyžádal od s vyslanectvím spolupracující pražské advokátní kanceláře rady, jak by měli dále postupovat. ${ }^{85}$ Od připravované exekuce pak bylo upuštěno ${ }^{86}$ Ochotu pražského vyslanectví se ve věci paní von Steiger/Walterskirchen angažovat jistě podpořila intervence švýcarského spolkového prezidenta Edmunda Schulthesse, který nabízel, že pošle osobní list československému prezidentovi Tomáši G. Masarykovi. Bruggmann tuto iniciativu sice $\mathrm{v}$ daném okamžiku považoval za předčasnou, připouštěl ji ale během rozhovorů o stanovení náhrady. Předpokládal, že se podaří vyjednat její podstatné zvýšení, protože ,, se Češi v zásadě snaži vyhnout potížím s cizinou, a proto jsou cizinci často lépe odškodněni než vlastní [českoslovenští - V. H. - J. Ž.] občané i než predpokládá legislativa o pozemkové reformě “" ${ }^{87}$

Na novou Bruggmannovu žádost o úlevy odpovědělo v záríí 1928 ministerstvo zahraničních věcí poměrně vyhýbavě. Zdůrazňovalo údajnou vstřícnost SPÚ,

81 BAR, Bestand E2200.190-03, Akzession 1000/318, Behältnis 8, Marie von Steiger EPD, 3. 2. 1928.

82 BAR, Bestand E2200.190-03, Akzession 1000/318, Behältnis 8, Bruggmann dr. Edmundu Turchányimu (advokát hr. von Walterskirchen), 2. 2. 1928, No. 8.a. 111/e.-B.

83 BAR, Bestand E2200.190-03, Akzession 1000/318, Behältnis 8, Anonym, Entschädigungsforderungen der Erbschaft Steiger, 2. 5. 1928.

84 Tamtéž. Velkostatek Lehota měl rozlohu 331 katastrálních jiter.

85 BAR, Bestand E2200.190-03, Akzession 1000/318, Behältnis 8, Hahn (advokát) švýc. vyslanectví, 12. 5. 1928.

86 BAR, Bestand E2200.190-03, Akzession 1000/318, Behältnis 8, Bruggmann EPD, 22. 5. 1928, No. 8-a-III-s.-B.

87 BAR, Bestand E2200.190-03, Akzession 1000/318, Behältnis 8, Bruggmann Schulthessovi, 8. 6. 1928. 
když velkostatku nakonec ponechal téměř 1200 jiter, což bylo více, než zákonem stanovená maximální rozloha. Pokud jde o ceny, upozorňovalo, že se SPÚ řídil při stanovení náhrady zákonem. Zpochybňovalo se tvrzení vlastnice, že si její matka v dohodách s SPÚ vyhradila s odvoláním na své švýcarské občanství právo požadovat za vyvlastněný majetek plnou náhradu. Podle ministerstva jen požadovala stejné výhody, jakých dosáhli jiní cizinci. Jako vstř́icný krok pak ministerstvo prezentovalo již v roce 1925 vydaný souhlas SPÚ s prodejem části velkostatku z volné ruky. V oblasti stanovení zbývající náhrady nebyly dány žádné konkrétní př́sliby. ${ }^{88}$ Státní pozemkový úrăad ve své informaci ministerstvu zahraničí, která se stala podkladem pro nótu, naznačoval, že by se paní von Walterskirchen měla snažit dohodnout na výši náhrady, protože jinak rozhodne jednostranně a nebude pak prostor po jinou, než úradem v této situaci obvykle stanovovanou kompenzaci. ${ }^{89}$

Bruggmann v reakci na československou nótu vlastnici znovu doporučoval zahájit prostřednictvím českého advokáta intenzivní jednání s SPÚ a sliboval novou intervenci ve vhodný okamžik. ${ }^{90}$ Současně československé úřady opět otevřely otázku daňových nedoplatků a hrozily exekucí. Paní von Walterskirchen však stále váhala. ${ }^{91} \mathrm{~V}$ únoru 1929 se ovšem ukázalo, že se rozhodla podruhé provdat, tentokrát za italského občana. Podle tehdejších švýcarských zákonů tím přišla o švýcarské občanství a pro pražské zastoupení konfederace tak nepř́ijemná kauza předčasně skončila. ${ }^{92}$ Paní von Walterskirchen nakonec SPÚ ponechal 1179 kat. jiter půdy, z toho 580 jiter zemědělské půdy. Šlo tedy o něco méně než polovinu původní rozlohy velkostatku Hajná Nová Ves..$^{93} \mathrm{Z}$ velkostatku Kamanová zůstalo po reformě dobrých 400 jiter půdy, tedy o něco více, než polovina původní rozlohy. Torzo velkostatku bylo prodáno v roce $1934 .{ }^{94}$ Vzhledem k tomu, že se oba velkostatky skládaly převážně ze zemědělské půdy a ležely v poměrně úrodných oblastech, lze tento výsledek považovat za úspěch. Vlastnice to však takto nevnímala a pod novým jménem Savioli se jako italská občanka přela se státem až do konce třicátých let.

88 BAR, Bestand E2200.190-03, Akzession 1000/318, Behältnis 8, čsl. min. zahraničních věcí Bruggmannovi, 26. 9. 1928, No. 115.715/II/28.

89 AMZV, VI. sekce, kt. 508, SPÚ min. zahraničních věcí, 30. 8. 1928, No. 101.772/ 28 - Z.

90 BAR, Bestand E2200.190-03, Akzession 1000/318, Behältnis 8, Bruggmann von Walterskirchen, 10. 10. 1928, No. 8a-III-c/B.

91 BAR, Bestand E2200.190-03, Akzession 1000/318, Behältnis 8, Bruggmann von Walterskirchen, 8. 12. 1928, No. 8-a-III-c/B.

92 BAR, Bestand E2200.190-03, Akzession 1000/318, Behältnis 8, W. von Steiger EPD, 27. 2. 1929, No. chybí.

93 AMZV, VI. sekce, kt. 508, Informace, bez data, zřejmě 1937.

94 SNA, ŠPÚ, L 1757, Šk. 2413, Stav pozemkového majetku rodiny Steiger Zamoyský pred a po pozemkovej reforme, bez data (asi 1935). 
Problémem zde byly zejména přejímací ceny za vyvlastněnou půdu, samotné vyvlastnění už nebylo možné zvrátit. Náhrada byla na většinu zbývajících pozemků (390 ha) stanovena dvěma rozhodnutími SPÚ z června a července 1933. Celkem šlo o téměř 630000 korun..${ }^{95}$ Cena za hektar dosáhla zhruba 1600 Kč a byla tak jen mírně vyšší, než v roce 1924. Stížnosti majitelky u československých soudů na výši přejímací ceny nebyly úspěšné. ${ }^{96}$ Státní pozemkový úřad přitom byl ochoten již dříve přiznat za tuto půdu náhradu až ve výši 1 milionu korun, vyžadoval však souhlas paní Savioli, která k tomu nebyla ochotna, protože se jí kompenzace nezdála dostatečná. Státní pozemkový úřad jí tak jednostranným rozhodnutím přiznal ještě méně. ${ }^{97}$ Vedle nízkých náhrad se pak paní Savioli potýkala s vysokými daněmi. Šlo zejména o dávku z majetku a př́růstku na majetku. Zde zaznamenala částečný úspěch, protože v roce 1930 musel být předpis dávky zrušen. Vedle toho bylo zastaveno probíhající exekuční rízení v oblasti přímých daní, a to až do stanovení přejímací ceny za velkostatek Hajná Nová Ves. ${ }^{98}$

Majitelka se v této situaci rozhodla požádat o pomoc italské úřady. Vyslanectví v Praze podniklo první intervenci v její prospěch v lednu 1932, kdy poukazovalo na údajné vady ve vyvlastňovacím a přídělovém rrízení. Část půdy prý byla v roce 1926 přidělena, aniž by předtím došlo $\mathrm{k}$ jejímu vyvlastnění. ${ }^{99} \mathrm{Z}$ výše uvedených rozhodnutí o přejímací ceně je zřejmé, že nebyla úspěšná. Podle evidence MZV poté došlo v komunikaci Prahy a Říma ve věci Savioli k delší odmlce. Pravděpodobně se čekalo na stanovení dosud neurčené přejímací ceny za většinu vyvlastněné půdy.

Nový italský zásah tak přišel až v lednu 1935. Italský vyslanec tehdy podpořil představy majitelky a naléhal, aby jí byla prriznána kompenzace ve výši srovnatelné s ostatními velkostatkáři, občany států bývalé Dohody. Konkrétně měla získat 8 až 10000 Kč za hektar a dále jí měla být snížena dávka z majetku a dědická daň. ${ }^{100}$ Ministerstvo zemědělství v reakci na italskou intervenci tvrdilo, že

95 SNA, ŠPÚ, L 1757, Šk. 2416, SPÚ, Rozhodnutí, 19. 6. a 3. 7. 1933, No. č. j. 84.806/33-II/4. a $91.316 / 33-\mathrm{II} / 4$.

96 Namátkou uvádím Usnesení Nejvyššího soudu z 9. 11. 1934, který zamítl stížnost proti rozhodnutí SPÚ ze 3. 7. 1933. SNA, ŠPÚ, L1757, Šk. 2412, Nejvyšší soud, Usnesení, 9. 11. 1934, No. č. j. R III661/34/2.

97 AMZV, VI. odbor, kt. 508, Anonym na MZV, Pozemková reforma na majetku cizích příslušníků. Steigerová, bez data a čísla (1937).

98 AMZV, VI. sekce, kt. 508, Ministerstvo financí ministerstvu zahr. věcí, 6. 2. 1930, No. Č. j. 133817/29-III/9a. Předpis dávky z majetku byl zrušen Nejvyšším správním soudem pro vady ř́zení, na které si stěžovala paní Savioli.

99 AMZV, VI. odbor, kt. 508, Anonym na MZV, Pozemková reforma na majetku cizích příslušníků. Steigerová, bez data a čísla (1937).

100 AMZV, VI. odbor, kt. 508, Anonym na MZV, Pozemková reforma na majetku cizích přísluš- 
se zesnulá paní von Steiger v červenci 1926 , uvolila odevzdati nemovitosti bez výpovédi “. ${ }^{101}$ Diplomatickému tlaku se pak nehodlalo podrobit. Je otázka, zda se $\mathrm{v}$ tomto př́padě ale přece jen nepohybovalo na tenkém ledě. $\mathrm{V}$ roce 1931 totiž tři svědci písemně před notářem osvědčili, že byla k souhlasu donucena nevybíravým tlakem zástupců SPÚ, kteří se dostavili do Hajné Nové Vsi. ${ }^{102} \mathrm{~V}$ tomto smyslu také paní Savioli v témže roce oslovila SPÚ. Tvrdila, že postup úřadu byl nezákonný a požadovala místo předběžně nabídnutého jednoho milionu korun kompenzace více než 9 milionů korun. ${ }^{103}$

Skutečnou pozornost však v Praze vzbudila až další intervence italské diplomacie z června 1936. Paní Savioli snížila své požadavky na 3 miliony korun, současně žádala o odpuštění dlužných daní a dávek ve výši zhruba 1,2 milionu Kč. ${ }^{104}$ Ministerský předseda Milan Hodža kvůli tomu telefonoval přednostovi IX. odboru ministerstva zemědělství (tedy bývalý Státní pozemkový úřad) Františku Novákovi. Přednosta pak pro Hodžu připravil písemný referát, ve kterém poukázal na to, že paní Savioli mohla od SPÚ získat o zhruba 400000 Kč více, kdyby byla ochotna se dohodnout a $v$ roce 1933 nemusel přjímací cenu jednostranně stanovit SPÚ. ${ }^{105}$ Ve stejném duchu pak Novák informoval ministra zemědělství s tím, že vyšší náhradu nelze přiznat, protože by pak byla vyšší, než přídělová cena. ${ }^{106}$ Takto bylo informováno i italské vyslanectví, které se ovšem se zamítavou odpovědí nebylo ochotno spokojit. V listopadu 1936 se proto znovu obrátilo na československé ministerstvo zahraničních věcí, které si vyžádalo stanovisko ministerstva zemědělství. To setrvalo na dosavadním stanovisku s tím, že majetek cizinců je pozemkové reformě podroben za stejných podmínek, jako vlastnictví československých občanů. Italové nato v létě 1937 sdělili, že paní Savioli nepovažuje podmínky kompenzace za uspokojivé. Ministerstvo proto v říjnu 1937 přistoupilo na osobní jednání s majitelkou. ${ }^{107} \mathrm{Zda} \mathrm{k}$ jednání došlo a jaké mělo event. Výsledky, není ze zachované dokumentace zřejmé. Z prohlášení advokáta paní Savioli se však zdá, že i Řím měl v zimě 1938 zájem o smírné řešení spo-

níků. Steigerová, bez data a čísla (1937).

101 Tamtéž.

102 AMZV, VI. odbor, kt. 508, Svědectví Františka Weisse ze 17. 11. 1931 a důchodního Juraje Austina a komorníka Františka Kellnera, obě z 22. 9. 1931.

103 SNA, ŠPÚ, S 1757, Šk. 2413, Savioli SPÚ, 14. 4. 1931.

104 AMZV, VI. odbor, kt. 508, Anonym na MZV, Pozemková reforma na majetku cizích př́slušníků. Steigerová, bez data a čísla (1937).

105 SNA, ŠPÚ, L 1757, Šk. 2413, Novák Hodžovi, bez data a čísla (7. 1936).

106 SNA, ŠPÚ, L 1757, Šk. 2413, Novák Kabinetu ministra zemědělství, 11. 9. 1936, No. K čj. M-584/3-36.

107 AMZV, VI. odbor, kt. 508, Ministerstvo zemědělství Ministerstvu zahr. věcí, bez data a čísla (asi 10. 1937). 
ru. ${ }^{108} \mathrm{~V}$ nadcházejícím dramatickém období československých dějin se však již kauzu von Steiger-Savioli nepodařilo dovést do konce.

Jednání paní Savioli s československými úřady tak nevedlo k podstatným úlevám při provádění pozemkové reformy. Důvod je třeba spatřovat především v její neochotě ke kompromisu. Kdyby zaujala flexibilnější postoj, mohla dosáhnout navýšení př́jímací ceny a zřejmě i úlev v daňové oblasti. Svou neústupností tak přišla o výhody, které by jí bývala mohla přinést podpora švýcarského a posléze italského vyslanectví v Praze. Průběh pozemkové reformy na velkostatku Hajná Nová Ves je tak nutné považovat za výjimku svého druhu, ostatní švýcarští (např. Geymüller) a italští vlastníci (např. Thun) dosáhli s podporou svých vlád změkčení pozemkové reformy zejména ve finanční oblasti. ${ }^{109}$

* Tento článek vznikl s podporou Grantové agentury České republiky (GAČR), projekt č. 17-07730S, který je řešen na Univerzitě Jana Amose Komenského Praha s. r. o.

\section{TSCHECHOSLOWAKISCHE BODENREFORM AN DEN GÜTERN DER AUSLÄNDER IN DER SLOWAKEI. FALL DES BARON-GESCHLECHTS VON STEIGER-MÜNSINGEN}

\section{VÁCLAV H O R Č I Č K A - J A N ŽU PAN I Č}

Die tschechoslowakische Bodenreform betraf in der Zwischenkriegszeit nicht nur Großgrundbesitzer mit der tschechoslowakischen Staatsbürgerschaft, sondern auch fremde Staatsangehörigen. Nach der Fachliteratur gehörte ihnen etwa 1/5 aller Böden, welche den Großgrundbesitzern gehörten. Die ausländischen Besitzer stellten eine bedeutende Komplikation bei der Durchführung der Reform dar, da sie sich mehr oder weniger der nachdrücklichen Unterstützung von Seiten ihrer Regierungen freuten. Die Studie konzentriert sich auf schweizerische Eigentümer, konkret auf den Fall des Großgrundbesitzes Hajná Nová Ves in der Südslowakei. Es ging um einen kleineren Gutshof (ungefähr von 2600 Katastraljochen). Er hatte in der Zwischenkriegszeit 2 Eigentümer. Zuerst die verwitwete Maria von Steiger, geborene Zamoyska, Witwe nach dem im Kanton Bern lebenden Bürger, Albert Baron von Steiger-Münsingen. Nach ihrem Tod im 1926 erwarb den meisten Grundbesitz ihre Tochter Marie Gräfin

108 SNA, ŠPÚ, L 1757, Šk. 2413, Hrubý (adv.) Novákovi, 3. 2. 1938.

109 V tomto smyslu informoval neznámého kolegu z okruhu švýcarského vyslanectví v Praze známý pražský advokát JUDr. Richard Schidloff, který zastupoval řadu zahraničních velkostatkářů. BAR, Bestand E2200.190-03, Akzession 1000/318, Behältnis 8, Schidloff anonymovi, 24. 1. 1927. 
von Walterskirchen später Savioli, die gegen Ende des 20. Jahrhunderts dank der neuen Trauung italienische Staatsbürgerschaft erwarb. Im Artikel wird nicht nur der eigene Verlauf der Bodenreform, sondern auch deren internationale Zusammenhänge analysiert. Die Internationalisierung dieser Angelegenheit begann dabei ziemlich spät, im Jahre 1925, als sich Frau von Steiger mit ihrem Ersuchen um Amtshilfe an die Ämter in der Schweiz wandte. Die Regierung in Bern stellte zwar das Recht der Tschechoslowakei, den Landbesitz der Ausländer zu enteignen, nicht in Frage, verlangte jedoch dafür entsprechende Kompensation. Den Eigentümern blieb schließlich weniger als eine Hälfte der Großgutbesitzgröße erhalten. Bei der Entschädigung für den enteigneten Grundbesitz und bei den Steuerentlastungen könnte es ein bisschen anders sein. Die schweizerischen und italienischen diplomatischen Interventionen verfolgten insbesondere dieses Ziel. Sie erreichten jedoch schließlich keinen Erfolg. Der Grund war die Tatsache, dass die Eigentümerin nicht bereit war, ihre finanziellen Anforderungen gegenüber den tschechoslowakischen Ämtern zu verringern. Die darüber geführten Diskussionen beendeten endgültig die dramatischen Entwicklungen im Mitteleuropa in den Jahren 1938-39.

Prof. PhDr. Václav Horčička, Ph.D.

Univerzita Jana Amose Komenského Praha Roháčova 63, 13000 Praha 3

a

Univerzita Karlova, Filozofická fakulta

nám. Jana Palacha 2, 11638 Praha 1

Česká republika

e-mail: horcicka.vaclav@ujak.cz

Prof. PhDr. Jan Županič, Ph.D.

Univerzita Jana Amose Komenského Praha

Roháčova 63, 13000 Praha 3

a

Univerzita Karlova, Filozofická fakulta

nám. Jana Palacha 2, 11638 Praha 1

Česká republika

e-mail: jan.zupanic@fff.cuni.cz 